\title{
A mesterséges intelligencia árazásbeli alkalmazásának várható hatásai
}

\author{
Danyi Pál \\ Budapesti Műszaki és Gazdaságtudományi Egyetem
}

\begin{abstract}
A TANULMÁNY CÉLJA
A mesterséges intelligencia (MI) technológiája, eszközei egyre több üzleti területen fognak elterjedni a közeljövőben, köztük a marketing és árazás szakterületein is. Célunk annak bemutatása, hogy az MI, és rajta keresztül az adatvezérelt megközelítések milyen hatással lesznek az árazásra, hogyan fogják újraírni a vállalatok jelenlegi árazási gyakorlatát.
\end{abstract}

\section{ALKALMAZOTT MÓDSZERTAN}

A koncepcionális tanulmányomban a korábbi részletes szekunder kutatásomon alapulva vizsgáltam meg a MI módszerek várható hatását. A kutatásom végigtekinti az árazás legfontosabb folyamati elemeit.

\footnotetext{
A KUTATÁS LEGFONTOSABB EREDMÉNYE

Kutatásomban bizonyítom, hogy az adatvezérelt, MI eszközökkel támogatott technológiák alapvető változásokat hoznak az árazásban a következő évtizedben. Kidolgoztam az optimális ár megállapításának egy lehetséges MI-alapú folyamatát. Javaslatot teszek az egydimenziós termékár három dimenzióra kiterjesztésére, ahol az idő és vásárló dimenziók is megjelennek.
}

\section{ÚJDONSÁGOK; GYAKORLATI JAVASLATOK}

Az értékalapú és dinamikus árazás nagymértékben el fog terjedni az MI-nek köszönhetően. A rezervációs ár, az árrugalmasság, és az optimális ár olyan mikroökonómiai elméleti fogalmak, amelyek az MI alkalmazásával gyakorlati jelentőségúvé válnak a marketingben: lehetséges lesz szinte bármilyen cég számára kiszámítani ezeket sokkal pontosabban, mint jelenleg, és ezáltal jelentősen növelni a profitot.

Kulcsszavak: mesterséges intelligencia, intelligens árazás, dinamikus árazás, gépi tanulás, adatvezérelt, optimális ár, személyre szabott ár 


\section{BEVEZETÉS}

A negyedik ipari forradalom drasztikus változásokat fog hozni nem csak a termelésben, hanem az alkalmazott üzleti modellekben is, többek között a marketing és árazási folyamatokban. Ahogy Rekettye (2018) megállapítja, a technológiák alkalmazásának hatására az árképzés határai egymástól távolabb tolódnak, és nagyobb mozgásteret kínálnak az árak alakítására. Jelen tanulmányban kifejezetten a mesterséges intelligencia (továbbiakban: MI) alkalmazásának következményeit vizsgálom a lakossági kereskedelmi árazásra nézve. Egy korábbi cikkemben (Danyi 2018) ismertetett szekunder kutatás eredményei alapján kellő alapanyag áll rendelkezésre, hogy részletesen elemezzem, milyen céljai, eszközei és hatásai lesznek az MI technológiák használatának az árazásban. Hipotézisem, hogy forradalmi változást hoz az MI az árakban és árazásban, mert fontos eszközként sikeresen felhasználható.

\section{AZ MI ALKALMAZÁSÁNAK CÉLJAI}

A lakossági piacon (B2C) az MI módszerek és technológiák árazásban való alkalmazását a kereskedői oldal kezdte el és forszírozza, hiszen náluk áll rendelkezésre a szükséges anyagi erőforrás. A vevői oldal egy ideig biztosan háttérbe fog szorulni, azaz nem lesznek rövid távon olyan automaták, amelyek jelzik, hogy mit, mikor, mennyiért érdemes megvennie a vásárlónak. (A vevői oldalról a 6. fejezetben szólok részletesebben.)

Az eladói oldal legfontosabb célja az MI alkalmazásával az, hogy automatikusan tudjon árakat megállapitani, azaz pontosan meg tudja mondani, hogy mit (terméket, szolgáltatást), kinek (milyen vásárló szegmenseknek, akár egyéni szinten), mikor és meddig, milyen áron kínáljon. Ezen túlmenően az alábbi konkrét célokat is megfogalmazza a kereskedő: az MI-vel

- maximalizálni lehessen a profitot az „optimális” árak meghatározásával; (itt az optimális elméleti fogalom, és a jelentése sem egyértelmü. Értelmezésére a tanulmányban sor kerül.)

- $\quad$ az árazás pontosabb legyen, figyelembe véve az idő és vásárlói igény (mikor és kinek) dimenziókat;

- extraprofitot lehessen elérni azokhoz a versenytársakhoz képest, akik nem alkalmaznak ilyen technológiákat;
- költséget lehessen csökkenteni: pl. automatikus árazó rendszerekkel, árazó robotokkal;

- gyors árazási döntéseket lehessen hozni a változó körülményekre reagálva.

A következökben megvizsgálom, hogy egyáltalán melyik az az MI eszközkészlet, amit fel lehet használni ezen célok eléréséhez.

\section{ESZKÖZÖK AZ ÁRAZÁSBAN}

Az MI oldaláról megközelítve három fő technológia-típus játszik kiemelkedő szerepet az árazásban, amelyek a Danyi (2018) tanulmány 5. táblázatában szereplö MI területek elemzéséből következnek: (1) gépi tanulás; (2) adatelemzésen, üzleti intelligencián alapuló MI algoritmusok, rendszerek; valamint (3) a kommunikációt újragondoló MI megoldások.

\section{Gépi tanulás}

A feldolgozott irodalmakból látszik, hogy jelenleg a gépi tanulás a legnépszerúbb MI technológia. $\mathrm{Az}$ árazás szakterületen belül a mélytanulás válhat elterjedtté, elsősorban az ármeghatározásra. Mit tanulhat egy árazási gép? Azt, hogy milyen tényezőket kell figyelembe venni és milyen mértékben ahhoz, hogy a megállapított ár a legnagyobb profitot eredményezze a kijelölt időszakra nézve.

A gépi tanulás (mélytanulás) elsősorban a klaszszifikációs és regressziós problémák megoldására kiváló, és sokkal pontosabb eredményeket lehet elérni vele, mint évtizedekkel ezelött. Ez a megközelítés a klasszikus regressziószámítási (matematikai statisztikai) algoritmusok képességeit messze meghaladóan, lényegesen komplexebb problémák megoldására alkalmas, mivel jóval több paramétert (szempontot, dimenziót) lehet figyelembe venni a modellezésnél, mint korábban. Az árazást tekintve tucatnyi, vagy akár több tucat paramétert figyelembe lehet venni mind a kereskedő, mind a vásárló oldaláról. Az MI képes megtanulni, hogy kinek, mit, és mennyiért érdemes kínálni, azaz meghatározható minden egyes termékre és termékkategóriára, hogy milyen áron milyen szegmentációjú ügyfelek lesznek a várható vásárlók. A regresszióval az határozható meg, hogy milyen áron hány vevö várható és mekkora profitot fog a kampány eredményezni meghatározott idöszakon belül. A klasszifikációs modell ennél egyszerübben csak azt vizsgálja, hogy a terméket az adott áron megveszik-e vagy sem.

A gépi tanulás szükséges sikerfeltétele, hogy legyen kellően sok historikus adat, amivel a modell pontossága folyamatosan javítható. 
A visszacsatolásos tanulás esetén azzal az információval tanítjuk a modellt, hogy a termék a kiszámolt áron elkelt-e vagy sem, ill. mennyi idő alatt. Ebből következik, hogy a gépi tanulás alapvetően a lakossági piacon működik, mert a szervezeti (B2B) piacok nagy részén nincs elég tranzakciós adat, kivéve persze a legnagyobb kereskedőket.

A gépi tanuló rendszerek nem kaphatók dobozos termékként, ahhoz még több év fejlesztés szükséges. Ennek oka, hogy a tanuló rendszereknél nagyon sokféle modell (neurális háló architektúra) és beállítási paraméter lehetséges, és nem tudjuk pontosan, hogy az egyes árazási problémákra milyen beállítások a legjobbak. Egyelőre kísérletezni kell a mélytanuló modellekkel, és azokból kihozni a maximumot az ún. hiperparaméterek hangolásával. Általánosan az várható, hogy a következö évtizedben a modellek fognak versenyezni egymással, és előbb-utóbb kialakulnak a legsikeresebb modellek egy-egy konkrét architektúrával, ill. paraméterhalmazzal.

\section{Az adatelemzésen, üzleti intelligencián alapuló MI algoritmusok, rendszerek}

Az árazás tágabb problémakörében nem feltétlenül a gépi tanulás vezet eredményre. Az alábbi területeken különféle MI technikák alkalmazhatók, úgymint döntésmenedzsment, marketing automatizálás, kognitív keresés, robot-alapú folyamat automatizálás (RPA), MI-vel támogatott üzleti intelligencia platform, ill. tartalom létrehozás (Danyi 2018). Röviden kifejtve ezek árazásbeli alkalmazását:

- Árfigyelés és árfelismerés: a képi és videó tartalmakban, hirdetésekben, reklámokban megjelenő árak gyors felismerése már MI technológiákat követel.

- Intelligens árösszehasonlítás: a termék megszerzésének teljes várható költségének kiszámítása, beleértve a szállítást, a garanciát, stb. Az MI megoldások segítenek kiválasztani azt a kereskedőt is, ahol a legjobb vásárlási élményt kaphatja a vásárló.

- $\quad$ Árkedvezmények rendszere: a kereskedők számára az optimális árkedvezmények kialakítása, amelyben felhasználhatók a gépi tanulás eszközei is.

- Árazási folyamat automatizálása: a teljes értékesítési folyamat kézbentartása, folyamatos fejlesztése nagyon komplex emberi tevékenység, amelynek során automatizálni lehet MI eszközök (pl. robot-alapú folyamatautomatizálás, megfelelőség, felhő robotika) segítségével, hogy milyen forrásokból milyen adatokat használjon az árazógép és az ár hol jelenjen meg, pl. online webáruházban, hirdetésben, vagy éppen utcai megállító táblán.

- Árazási szakértő rendszerek: az árazás a számokon, számításokon túl számos szabály, fogalom, tudáselem megfelelő alkalmazását is jelenti, beleértve az árazási stratégiát, árpszichológiát, jogszabályok közötti eligazodást.

- Árjegyzékek, katalógusok automatizált létrehozása, karbantartása: MI eszközök felhasználása hibák, inkonzisztens árazások kimutatására. Az árjegyzékek rendszeres, sőt folyamatos megújítása szintén támogatható, helyettesíthető automatikus eszközökkel.

\section{A kommunikációt újragondoló $\mathrm{MI}$ megoldások}

Egészen újszerü az a megközelítés az árazásban, ami a több évezredes hagyományos adás-vételi gyakorlatot, az alkudozást gépesíti. A kereskedői oldalon az MI által müködtetett alkudozógép tudni fogja, hogy meddig mehet el a kedvezményekben. Az ember-gép kommunikációnak ezen a területein (pl. chatbotok, érzelemfelismerés, biometrika, számítógépes látás és képfelismerés) a határ az ember teljes helyettesítése: a gép figyelheti a vásárló reakcióit, metakommunikációját, akár arcmimikáját. A jövőben a gép tökéletesen ki fogja ismerni a vásárlót abban, hogy meg akarja-e venni a terméket vagy sem az adott áron, van-e értelme még tovább alkudozni, természetesen nagyszámú esetet elemezve. Valószínúsíthető, hogy a gép meg fogja tudni határozni a vevő rezervációs árát, azaz azt a legmagasabb összeget, amiért még hajlandó megvenni az ügyfél a terméket.

A robotizált személyes asszisztens (pl. Amazon Echo, Google Home) egy fontos változata lesz a jövőben a vásárló asszisztens, amely szól, ha valami jó akciót talált. Ehhez persze meg kell tanulnia a gazdája preferenciáit, illetve ismernie kell a rendszeresen felmerülő vásárlási rutinok mellett az egyedi igényeket is. Speciális változatban ingatlanra, autókra, utazásra szóló ,akcióvadász” MI rendszerek is meg fognak jelenni. 


\section{AZ MI HATÁSA AZ ÁRAZÁSRA}

Noha az előzőekben ismertetett MI alkalmazások egy része futurisztikusnak tünhet, azok nagy többsége minden bizonnyal meg fog valósulni a következő egy-két évtizedben. mert ezekre az alkalmazásokra szükség lesz akár a kereskedői, akár a vásárlói oldalon. A következőkben megvizsgáljuk, hogy mindezen MI alkalmazások milyen változást hoznak, várhatóan milyen hatásuk lesz az árazási folyamatra, ill. az egész vásárlási tevékenységünkre, szokásainkra (1. ábra).

\section{1. ábra: Az MI várható hatásai az árazásra}

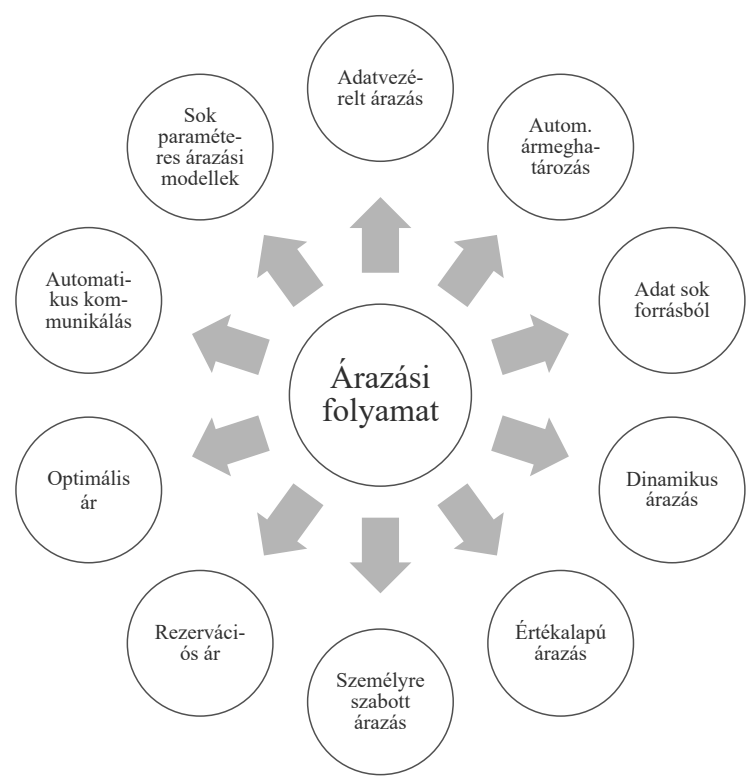

Forrás: saját szerkesztés

\section{Árazási folyamat}

$\mathrm{Az}$ árazási folyamat, akár az értékesítési, akár a marketing vállalati folyamat részeként várhatóan jelentősen megváltozik az MI eszközök bevezetésének hatására:

- Egyre fontosabb lesz az adatelemzés felhasználása, és adattudósok alkalmazása az árazásban. A jelenleginél sokkal több adatot kell majd begyüjteni.

- A következő évtizedben a modellek, algoritmusok fognak versenyezni egymással (mint ahogy a gépi tanulás különböző módszereinél, paraméterezéseinél látható manapság is).

- Azármeghatározás folyamata automatikus szabályozási folyamattá válik, amelyben minden tranzakció (általános értelemben véve minden ERP és CRM tranzakció, tehát a vevői érdeklődéstől kezdve az eladáson át az utókövetésig) adatai visszacsatolódnak az elemző rendszerbe, amiből az árazó motor automatikusan módosítja az árakat.

- Az árak előzetes meghatározása nem feltétlenül egy konkrét árcímkét jelent majd, hanem egy intervallumot, amelyen belül a gép a vásárlónak egyéni kedvezményt adhat, vagy a vevő alkudozással befolyásolhatja a végső ár kialakítását. Az árazási folyamatot tehát fel kell készíteni arra, hogy nagyobb teret adjon az interaktív árkialakításnak.

Az árazás marketingen belüli szerepe jelentősen változni fog: ahogy a keresletet nem csupán az árak határozzák meg, hanem a marketing mix (4P) többi eleme is, úgy az MI eszközök jól 
használhatók annak meghatározására, hogy az árazás milyen összefüggésben áll a mix további elemeivel. Sokkal szorosabban kapcsolódni fog az árazás a hirdetésekhez, a csatorna megválasztásához, magához a termék vagy kosár ajánlásához is. Évtizedekre munkát fog adni a marketingeseknek, hogy megfejtsék, milyen hatással van a termékre, a helyre és a promócióra, ha az árakat csökkentjük vagy növeljük, és fordítva: milyen módon kell átstrukturálni a termékeket, a csatornákat, vagy az ügyfélszegmenseket, hogy árakat tudjunk emelni és növelhessük a profitot. Csak a marketing-mix integrált, holisztikus megközelítésével lehet megcélozni annak a kereskedői végső célnak az elérését, hogy annak kínáljuk a terméket, akit érdekel, akkor, amikor érdeklődik, és annyiért, amennyiért megveszi.

\section{Adatvezérelt árazás: adatok elemzése számos forrásból}

Az adatvezérelt árazás szükséges feltétele a nagy mennyiségü adat, amit számos forrásból kell majd begyüjtenie a közeljövő kereskedőjének. Az alábbi táblázat szerint három forrásba soroltam az adatforrásokat: (a) saját üzleti müködésben létrejövő és elérhető adatok, (b) más kereskedők, piaci szereplők elérhető adatai, (c) a vevők viselkedéséből származó és származtatható adatok.

\section{1. táblázat: A kereskedők három fő adatforrása az adatvezérelt árazáshoz}

\begin{tabular}{|c|c|c|c|}
\hline Adatforrások: & Saját & Piaci & Vevői \\
\hline $\begin{array}{c}\text { Kereskedó árazási } \\
\text { célja: mit, mikor } \\
\text { mennyiért érdemes } \\
\text { kínálni. }\end{array}$ & $\begin{array}{c}\text { Saját költségek és érté- } \\
\text { kesítési számok alapján } \\
\text { árlimitek meghatáro- } \\
\text { zása. }\end{array}$ & $\begin{array}{c}\text { Más kereskedők figye- } \\
\text { lése (versenytárs árak). } \\
\text { Iparági elemzések. }\end{array}$ & $\begin{array}{c}\text { Vevőviselkedés elem- Kereslet figyelése. } \\
\text { Személyre szabott } \\
\text { árazás. Rezervációs ár } \\
\text { meghatározása. }\end{array}$ \\
\hline
\end{tabular}

Forrás: saját szerkesztés

Az adatok gyüjtése, tisztítása, előkészítése, majd a feldolgozása költséges, időigényes folyamat. A hagyományos tranzakciós adatokon túl szükség lesz egyéb nem-strukturált adatok felhasználására is közösségi oldalakról, videó oldalakról, kommentekből, stb. Az ehhez szükséges szakértelmet is új, még ritka, és igen keresett szakemberek tudják csak biztosítani, mint például adattudósok, vagy az adatvagyon gazdálkodási vezető (Chief Data Officer).

A GDPR rendelkezések jogszabályi feltételei nem tiltják a vásárlói adatok gyüjtését, de azokhoz vásárlói hozzájárulás szükséges. A kereskedők várhatóan kedvezményekkel, ajándékokkal, törzsvásárlói elönyökkel fogják bátorítani az ügyfeleket a hozzájárulás megkötésére. A nem rendelkező ügyfelek anonim elemzése, profilírozása pedig változatlanul lehetséges lesz.

\section{Dinamikus árazás}

A dinamikus árazást kereslet-kínálat alapú árazásnak is tekinti a szakirodalom. Den Boer (2015) szerint az optimális ár meghatározását jelenti olyan esetekben, amikor az árak könnyen és gyakran változtathatók. Rekettye és Liu $(2018,169)$ értelmezésében a vevők árelfogadási hajlandósága (várható kereslet) és a rendelkezésre álló termékvolumenek, kapacitások (kínálat) pillanatnyi állapotából levezethető hozammenedzselésként érthetjük, azaz minden időpillanatra megállapítható az az ár, amellyel a vállalkozás maximalizálja a profitját.

Noha a dinamikus árazás közel 40 éve használatos gyakorlat, a bonyolult számítási modellek és a korlátos számítógépes kapacitások miatt csak az utóbbi 10-15 évben kezdett elterjedni, föleg a turizmus területén. Semmiképp nem mondható, hogy a dinamikus árazásnak szükséges feltétele lenne a MI, hiszen anélkül is sok területen számíthatók a kereslet-kínálati egyensúlyok. Két lépésben viszont jól felhasználható az MI: egyrészt a várható kereslet előrejelzésében, másrészt annak a függvénynek az algoritmizálásában, amelyik 
előállítja a javasolt árat a tényleges és várható kereslet különbségéből, valamint a kínálati adatokból (2. ábra). Ennek során az MI megközelí tések (főleg a gépi tanulás, azon belül a mélytanulás) lehetővé teszik az egyre több paramétert tekintetbe vevő modellek szerinti számítást, egyre pontosabb árakat megállapítva, egyre növelve a profitot.

\section{2. ábra: Az MI jól felhasználható a várható kereslet előrejelzésében a dinamikus árazás során}

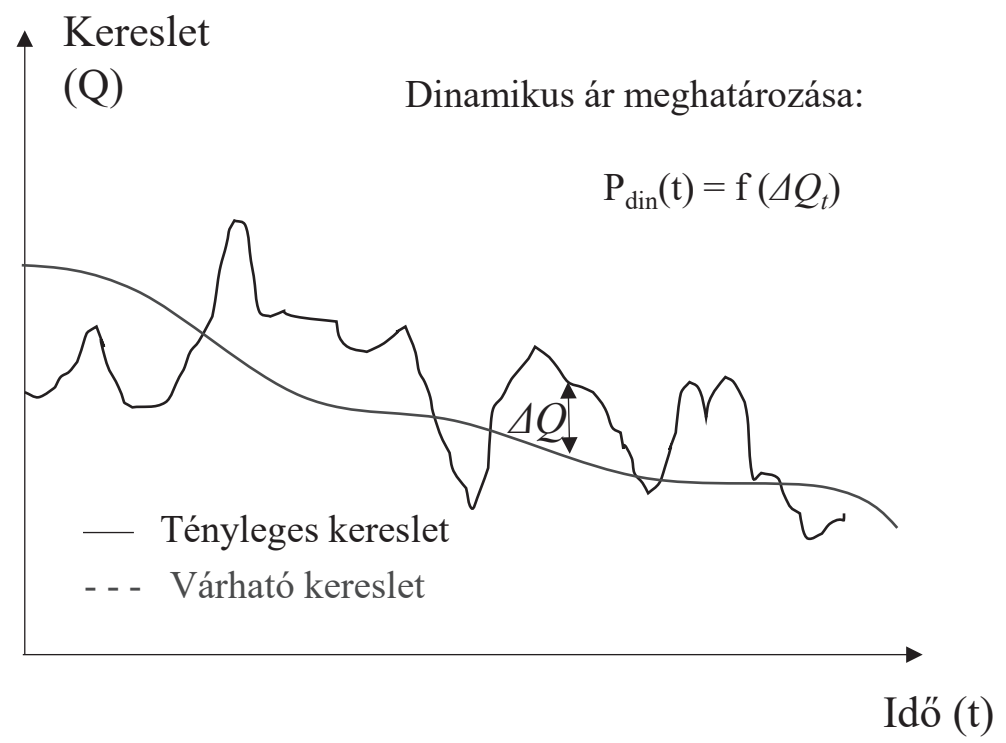

Forrás: saját szerkesztés

Várható tehát, hogy az MI térhóditásával a dinamikus árazás egyre jobban elterjed a turizmuson kívül is minden olyan esetben, ahol a kereslet és kínálat pillanatnyi értékei szerinti árazás alkalmazható és a vásárlói oldalon elfogadható. (Az etikai kérdéseket terjedelmi korlátok miatt nem érintjük.) A mozik, színházak, fesztiválok, sportesemények jegyeinek árazása részben már dinamizálódott az elmúlt években (és több országban elindultak ez irányú kísérletek), csakúgy mint az energia ára: az aktuális felhasználás megszabja az árakat. Manapság jellemzően azokon a területeken népszerü, ahol a kínálat korlátos, vagy nehezen bővíthető.

\section{Értékalapú árazás}

Az értékalapú árazás lényege, hogy „,a fogyasztók vásárlási döntésében az érzékelt, észlelt vagy elfogadott érték játszik döntő szerepet: ez az, ami a vásárlási hajlandóságot alapvetően meghatározza." (Rekettye 2012) Az észlelt érték szerinti árképzés az elmúlt két évtized legnépszerübb elmélete az árazási szakirodalomban. Ugyanakkor a gyakorlati terjedésének gátat szab, hogy igen bonyolult módon lehet csak modellezni azt, amit a termék nyújthat a vevőnek. Ráadásul a vevő nem csupán egy árat érzékel és értelmez, hanem azonnal hozzákapcsol egy összetett értéket, röviden hasznosságot a kívánt termékhez. Ha az ár és a hasznosság közel azonos szinten van, akkor megtörténhet a vásárlási tranzakció. Továbbá az is kihívást okoz, hogy minden vásárlószegmens, sőt akár egyénileg is, más-más értéket tulajdonít a terméknek. Ha a kereskedő nem vesz tudomást a vásárlók értékelési eltéréseiről, akkor ugyancsak profitot veszít. Az értékalapú árazás a megkülönböztető értékről szól. (Macdivitt - Wilkinson 2012, 19). Ezt a termékre, szolgáltatásra, vagy éppen a kereskedőre vonatkozó megkülönböztető értéket kell meghatározni és mérni, aminek alapján árazni lehet majd.

Az MI alkalmazásával ezek a fogalmak (érték, hasznosság, vásárlási hajlandóság) pontosabban 
mérhetővé válnak, így az értékalapú árazás gyakorlata jelentősen kibővülhet. MI-vel egyrészt előre jelezhető, hogy jelenleg mekkora hasznosságot érzékel a vevő, és ennek alapján a szükséges hirdetés, reklámozás is megbecsülhető, azaz annak mértéke, hogy mennyivel kell növelni az észlelt értéket az érdeklődést felkeltéséhez és a vásárlási hajlandóság megszületéséhez. A vásárlási igény felkelthető pl. az ún. rezervációs árral, vagy annál alacsonyabb „visszautasíthatatlan” árral. A termék hasznossága szubjektív a vásárló számára, éppen ezért a vásárlás számos érzelmi, irracionális elemet is tartalmaz. Az MI eszközökkel egyre több ilyen szubjektív elem érvényesíthető az értékszámítás során, például a vevő olyan igényei is, mint a divatkövetés, a „barátnak/szomszédnak már bevált” vagy „Karácsonyra/ ünnepre sürgősen kell" szempontok.

Ha a kereskedőnek sikerül - MI segítségével a termék várható észlelési értékét, hasznosságát jó közelítéssel megbecsülni, akkor az egyedi vásárló szintjén egy személyre szabott ár is adható, illetve nagy tömegek esetén értékalapú szegmensekbe sorolhatók a vásárlók, nem csak árazás, hanem egyéb marketing célokból is (pl. hirdetés, reklámozás különbözö csatornákon). Az árazógéphez kapcsolt hirdetögép segíteni fog abban, hogy minden ügyfél annyiért lássa a terméket hirdetni (személyre szabottan), amennyiért még éppen hajlandó megvenni, mert megfelelően magas értéket lát benne. Egy gyüjtő például többet hajlandó adni egy ritka könyvért, mint egy átlagember. (Erre a gondolatra épülnek az aukciók.) Példa kedvéért meg kell határozni egy sportcipő árát. Először azonosítani kell azokat a potenciális vevőket, akik akár 30 ezer forintot is megadnának érte, és számukra kell hirdetési kampányt indítani. Utána le lehet szállítani a termék árát 25 ezer forintra, majd harmadik körben 20 ezerre, és közben kampánnyal megcélozni azokat a vevőket, akik számára megér annyit.

Ha jelentős különbség adódik az észlelt érték és a kínált fogyasztói ár között, akkor az MI segítségével olyan kereskedöi döntések is segíthetők lesznek, miszerint plusz értéket kapjon az ügyfél, aminek örül, pl. ingyenes szállítás, kiterjesztett garancia, stb. Olyan win-win helyzeteket képes az MI azonosítani, amelyekben mindkét fél elégedett lesz, és ez kompenzálhatja az MI költségét, hiszen egyébként az ügyfél nem vette volna meg a terméket. Az árpszichológia is jelentős fejlődés előtt áll: MI módszerekkel befolyásolható lesz a vevő (akár tudat alatt), hogy mennyire tartson hasznosnak egy terméket, vagy mikor vegye meg, milyen feltételekkel.

Az érték és hasznosság mérésének alapfeltétele a vevőkről szerzett széleskörủ adatok, információk elemzése, tehát a kereskedőnek rendelkeznie kell megfelelő mennyiségü és minőségü adattal az ügyfeleiről. A jelenlegi gyakorlat szerint csak a törzsvásárlókról vannak adatok, de azok elemzése sem történik meg rendszeresen, és igen kevés célra használják az elemzés eredményeit. Az MI terjedésével valószínüsíthető, hogy a legkülönfélébb vásárlói adatok gyüjtése és kiértékelése fog megtörténni, amit néhány példával illusztrálunk:

- Milyen komoly a vevő vásárlási szándéka? Ha sok oldalt megnézett, kutakodik az interneten, akkor bizonyára fontos neki a téma és vásárolni akar.

- Mennyire szakértője a termékcsoportnak, ismerője a helyettesítö termékeknek?

- Mennyire árérzékeny a vevő, mikor és mennyiért vásárol: csak akciósan, vagy mindegy, hogy mikor?

- Milyen gyorsan van szüksége a vevőnek a termékre? Azonnal, holnap, vagy ráér két hét múlva, pl. regionális raktárból ideszállítani?

- Mennyire konkrét típust igényel a termékből? Esetleg más színben? Esetleg kicsit más paraméterrel? És arra tud-e nagyobb kedvezmény adni a kereskedő?

\section{Az „optimális” ár}

Egy konkrét termékre azt az árat tekintjük optimálisnak, amit megváltoztatva csökken a profit egy meghatározott idökereten belül, tehát egy globális maximumot jelent. (A profit számításába beleértjük a kereslet ártól való függését.) Az optimális ár új megközelítést kap az MI világban. Mindeddig az „optimális” meghatározása túlságosan idealizált, elméleti matematikai volt a hétköznapi életben. Mindössze annyit lehetett sejteni, hogy a listaár és a kereskedő számára - valamilyen módon - meghatározott minimálár között van egy mozgástér, ami például lehetővé teszi az akciókat, árkedvezményeket (lásd 3. ábra). A szó szoros értelmében optimális ár sosem lesz elérhető, hiszen az mindig csak egy leszükített kontextusban lesz optimális, a vásárlás világa azonban sosem zárt. A reális célkitüzés a gyakorlatban az lehet, hogy a jelenleginél sokkal jobban megközelítjük a valós vásárlási folyamatot, kevesebb elhanyagolással kell élnünk, azaz egyre több paramétert vehetünk figyelembe a modellünkben. Optimális árként - jelen tanulmányban - tehát a gyakorlati megközelítést, az egyre jobban megközelíthető profitoptimalizálást értjük. 


\section{3. ábra: Az optimális ár a profit maximalizálását ígéri (szemléltető ábra)}

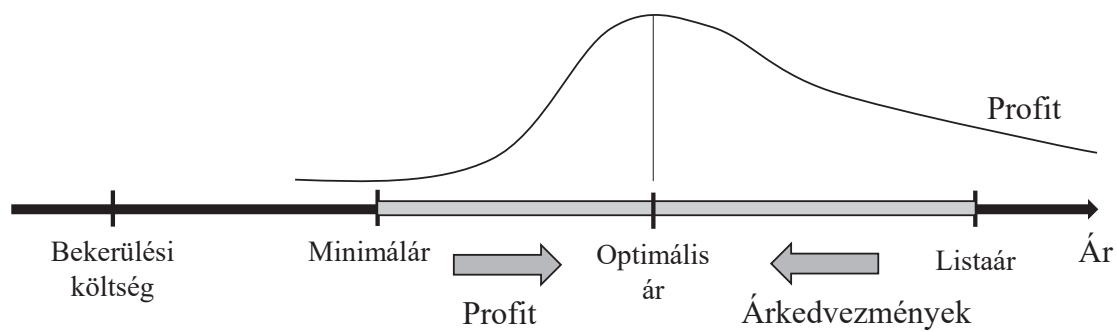

Forrás: saját szerkesztés

Az optimális ár megállapításának jövőbeli, MI által támogatott folyamatára nincs még tudományosan kidolgozott lépéssorozat. A következő fejezetben megkíséreljük egy lehetséges folyamat bemutatásával bizonyítani az MI transzformáló erejét.

\section{AZ OPTIMÁLIS ÁR MEGÁLLA- PÍTÁSÁNAK FOLYAMATA}

$\mathrm{Az}$ egyes termékek optimális árának megállapítása lehetővé válik MI segítségével a következők folyamat szerint, ami egy új, gyakorlati szempontból megvalósítható lépéssorozatot jelent:

1. A vizsgált termék kapcsán kiszámítjuk az árrugalmasságot, ami megmutatja, hogy várhatóan milyen mértékben fog változni a kereslet, ha csökkentjük vagy növeljük az árat.

2. Az árrugalmasság számítást finomítjuk az ügyfeleinkre meghatározott rezervációs ár-becslésekkel.

3. A várható kereslet és a költségeink alapján kiszámítható a várható profit. A maximális profithoz tartozó ár lesz az optimális ár.

4. Az optimális termékár kiterjeszthető két és három dimenzióba is, figyelembe véve az idő és vásárló dimenziókat. Ezzel egy háromdimenziós tér minden egyes pontjához rendelhetünk optimális árat, vagy úgy is mondhatjuk, hogy az optimális áraknak egy háromdimenziós „,elületét" hozhatjuk létre a négydimenziós térben.

5. Szegmensekre, sőt személyre szabottan tudunk árat, sőt optimális árat kínálni, ami a termék általános optimális árától eltérhet.

6. A tényleges eladási számok visszacsatolása alapján módosítjuk a rezervációs árat, az árrugalmassági függvényt, és ennek alapján frissíteni lehet az optimális árakat.

A következőkben részletesen végigtekintjük az egyes lépéseket (az utolsó kivételével).

\section{Az árrugalmasság meghatározása}

Az árrugalmasság, mint az árazás mikroökonómiai alapfogalma, megmutatja, hogy egy termék esetén a fogyasztói árak változtatása milyen függvénykapcsolatban áll a kereslettel. Az árrugalmasság számítása - a kereskedők számára - mindeddig alapvetően elméleti tevékenység volt, mert többféle korlátba ütközött az adatgyüjtés a gyakorlatban: hosszú ideig kellett figyelni egy termék fogyását egy konkrét áron, valamint az árakat is rendszeresen kellett változtatni mindkét irányban. Komoly publikációnak minősült, amikor egy-egy termékre vagy termékcsoportra sikerült „,pontos” adatokat számítani, vagy jól definiált körülmények közötti vásárlások elemzésével közelítő árrugalmasságot megállapítani.Állítom, hogyegyretöbblehetőségünk lesz megbízható árrugalmasságot számítani a következők szerint:

- közvetlenül rendelkezésre állnak nagy tömegủ keresleti adatok, például historikus tranzakciós adatok, amelyekből meghatározható az árrugalmassági függvény,

- tudatosan ,játszanak” a kereskedők az árakkal, és rögzítik, hogy bizonyos árengedmények vagy árnövelések mennyiben hatnak a keresletre,

- egyre több piaci szereplő fog árrugalmasságot számítani globális, nemzetgazdasági, vagy éppen gyártói szinten, amely adatok - valamilyen formában, publikusan vagy elöfizetéssel elérhetők lesznek a kereskedők számára. 
Az így meghatározott árrugalmasság nem az egyes vevőkre szól, hanem a vevők összességének keresletére. A konkrét kereskedelmi tranzakcióban azonban a konkrét vásárló számára kell árat kínálnunk, tehát érdemes az általános árrugalmasságot finomítani a vevőkre vonatkozó információk, például a rezervációs ár felhasználásával.

\section{A rezervációs ár meghatározása}

Az MI-alapú árazógépek várhatóan egyre pontosabban meg tudják majd becsülni a mikroökonómiából jól ismert rezervációs árat, így az eladó megtudhatja, hogy maximum mennyit lennének hajlandók fizetni a vevőjelöltek az aktuális körülmények között. Ez azért is forradalmi, mert a vásárlók többsége nem egy konkrét árlimittel indul vásárolni, és a rezervációs árat legtöbbször maga a vevő sem tudja - részben azért, mert az a vásárlás vagy ártárgyalás folyamán változhat, másrészt olyan tényezőktől függhet, amelyeknek nincs közvetlen köze a tranzakcióhoz (pl. egészségügyi állapot, munkahelyi stressz, boldogságérzet, elöítélet).

A rezervációs árak meghatározásához nincs egyértelmű módszer, de számos lehetőség áll rendelkezésre már most is közelítő számításokat végezni:
- Elsősorban az eddigi vásárlási adatok állnak rendelkezésre, de nem a közvetlen tranzakciós adatok (termék, ár, volumen) lesznek érdekesek, hanem az elemzéssel nyert következtetett adatok: ki, mikor, és milyen körülmények között vásárolt, mennyire árérzékeny, csak akciók, árkedvezmények során vásárol, vagy máskor is, esetleg egyáltalán nem érdekli az ár.

- A „vevői érték” és hasznosság méréseket érdemes lefolytatni, amelyeket az Értékalapú árazás fejezetben már említettünk.

- A már említett alkudozási folyamat elemzése szintén információt jelent az ügyfélről, ami segíti a számítást.

- A kereskedő saját adatbázisa csak a meglévő ügyfelek adatait tartalmazza, de az árösszehasonlító szolgáltatók támpontot tudnak adni a minimálárra, ami sok vevőjelölt számára jelenti a rezervációs árat.

A vevői érdeklődésre nézve (átkattintások) az adatok jellemzően ismertek vagy anonimizáltan megvásárolhatók a szolgáltatóktól.

\section{4. ábra: Vevői rezervációs árak eloszlásfüggvénye (példa adatok alapján)}

1200

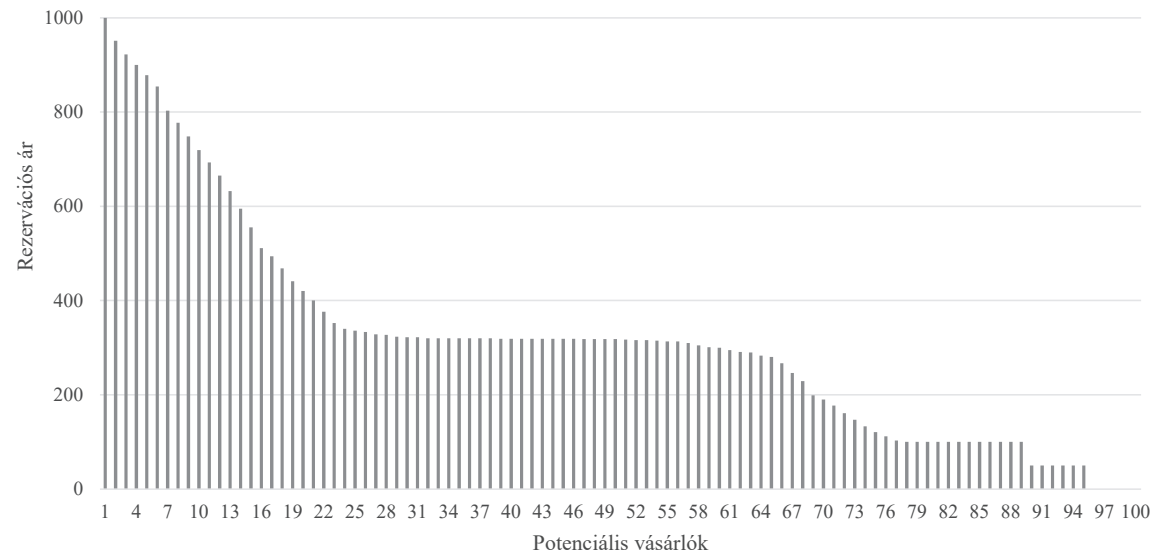

Forrás: saját szerkesztés 
A 4. ábrán példaként látható, hogy csökkenő sorrendbe rendezve a rezervációs árakat, jól elkülöníthetők az ügyfelek szegmensei, és felhasználhatók a vásárlási hajlandóság előrejelzésére.

A vásárlók rezervációs árának meghatározása nem csak az egyes vásárlók számára történő eladási ár szempontjából fontos, hanem azért is, mert inputként ez a legfontosabb adat az árrugalmasság meghatározásához. Ha ismerjük több száz, vagy több ezer vásárlónk rezervációs árát, akkor becsülni tudjuk az egyes termékek árrugalmasságát. Vagyis minden egyes árhoz meg tudjuk határozni a várható keresletet, hiszen csak azok fognak vásárolni, akik rezervációs ára nagyobb vagy egyenlö, mint az ajánlott fogyasztói ár.

\section{Az optimális ár meghatározása}

Az árrugalmasság alapján optimális árat lehet számítani az egyes termékekre. A korábbi definíció szerint ehhez a profitot kell meghatározni az ár függvényében. Első lépésként az árrugalmassági függvény alapján meg tudjuk becsülni a keresletet az egyes árértékekhez. A profit meghatározása ezután egyszerüen történik az ár, a kereslet és a fix költségek alapján, a jól ismert összefüggés szerint (pl. Smith 2012, 5)

$$
\pi=\mathrm{Q} *(\mathrm{P}-\mathrm{V})-\mathrm{F},
$$

ahol $\pi$ a várható profit, $\mathrm{Q}$ a becsült kereslet, $\mathrm{P}$ a javasolt ár, $\mathrm{V}$ a változó költség, és $\mathrm{F}$ a fix költség. $\mathrm{Az}$ 5. ábrán szereplő példában az egyszerüség kedvéért csak fix költséggel számoltuk.

Az így felrajzolt profitfüggvény alapján meghatározható az optimális ár, ha a költségadatok pontosan ismertek. Kifejezetten az optimális ár meghatározásához nincs szükség MI-re, ha az árrugalmasságot és a költségeket ismerjük.

\section{5. ábra: Az optimális ár meghatározása a kereslet- és profitszámításból (példa adatok alapján)}

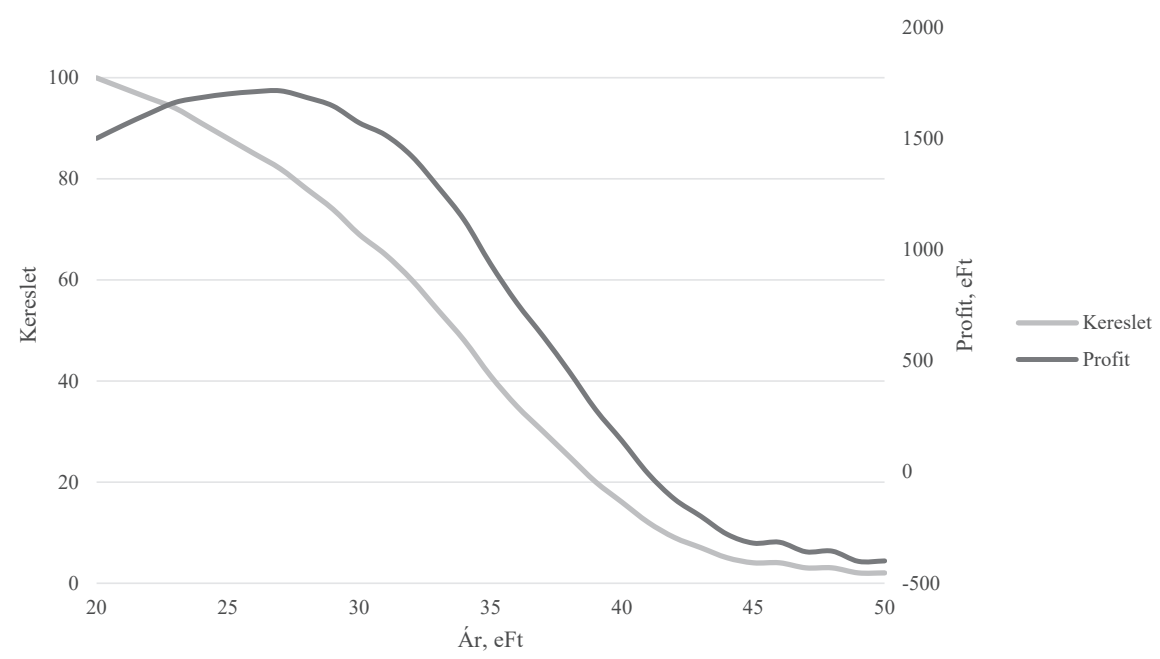

Forrás: saját szekresztés 


\section{Az optimális ár két és három dimenzióban}

A kereskedelmi árazás alapvetően azért bonyolult, mert az ár egy három dimenziós tér minden pontjára értelmezhető. Az egyik dimenzió a forgalmazott termékek köre, a másik dimenzió az idő, tehát a meghatározott ár érvényességi ideje, a harmadik pedig a vásárló, ill. a vásárlói szegmensek, hiszen nem biztos, hogy mindenkinek azonos áron kell adni egy terméket. A jelenleg elterjedt árazás egy (a termék), vagy legfeljebb két (termék és idő, vagy termék és vásárló) dimenziót vesz figyelembe. Az egyes termékekre eddig meghatározott „optimális ár” időtől és vásárlótól független, egydimenziós érték volt. Az optimális árat viszont meghatározhatjuk idődimenzióban, vagy vásárlói dimenzióban (vásárlói szegmensek szerint), vagy akár mindkettőt figyelembe véve három dimenzióban is. $\mathrm{P}$-vel jelölve az árat, $\mathrm{A}$-val a terméket, $t$-vel az időt, $C$-vel a vevőt, $\alpha, \beta, \gamma$.. betúkkel pedig az ármeghatározás további független változóit, mint például mennyiség, raktárkészlet, beszerzési ár, vevői árérzékenység, stb.), azt mondhatjuk, hogy a

$$
\mathrm{P}=\mathrm{f}(\mathrm{A}, \mathrm{t}, \mathrm{C}, \alpha, \beta, \gamma \ldots) \text { helyett a } \mathrm{P}(\mathrm{A}, \mathrm{t}, \mathrm{C})=
$$

$$
\mathrm{g}(\alpha, \beta, \gamma \ldots)
$$

függvény fogja leírni az árazás képletét. Röviden: skalármezö helyett vektormezö fogja leírni az árazást. Ennek gyakorlati szempontból annyi a jelentősége, hogy néhány év múlva értelmetlen lesz egy termék egydimenziós áráról beszélni idő és vevő dimenziók nélkül.

Az időben változó optimális ár azt jelenti, hogy rendszeres időközönként számítunk rezervációs árat, árrugalmasságot. Az idődimenzió skálája többféle lehet: folytonos, néhány óránként, néhány naponta. Ha csak egy-egy napra, hétvégére, rövidebb időszakra értelmezzük az optimális árat, akkor ezt a kereskedelemben árkedvezmény optimalizálásként tekinthetjük. Következmény tehát, hogy az MI eszközök alkalmazásával a jelenlegi árkedvezmények rendszere is teljesen átalakul: gyakran változó, akár pillanatnyi árak lesznek. Ha természetessé válik, hogy az aktuális kereslet hatására változik az árrugalmasság, akkor termékek ára is fog, akár naponta többször is. Ez már a dinamikus árazáshoz vezet.

A vásárlószegmensek szerint is lehet optimális árakat meghatározni. A szegmensek szerinti árdifferenciálás történelmi idők óta jelen van a gyakorlatban: legegyszerübb formában árkedvezményt jelent bizonyos vásárlói csoportok számára, például diákok és nyugdíjasok részére. Az elmúlt évtizedben lehetővé vált, hogy az online kereskedők folyamatosan figyeljék és elemezzék a vásárlói szokásokat, akár az egyes vevő szintjén is, és ennek alapján valós időben változtassanak árat (Bara 2017).

A marketingben megszokottól eltérő szegmentálás lehet az, hogy a rezervációs árgörbe (4. ábra) szerint osztályozzuk a vásárlókat. Így minden szegmensnek különböző árakat kínálhat a kereskedő, illetve ezzel egyenértéküen (csak más kommunikációval) eltérö mértékủ kedvezményeket vagy más járulékos értéket (szállítás, stb.) ajánl neki. A különböző vevőkörökre más ár lesz az optimális.

$\mathrm{Az} \quad \mathrm{MI}$ terjedésével várhatóan elterjed a néhány tucatnyi vevőre vagy akár néhány före vonatkoztatott mikroszegmentáció, aminek szélsőséges formája a teljesen személyre szabott árazás. A mikroszegmentációnak azért lesz létjogosultsága, mert az értékalapú árképzés szerint az egyes szegmenseknek más és más a termékről alkotott hasznosságképe, azaz a termék birtoklásának vagy szolgáltatás igénybevételének észlelt értéke, és az MI-vel kellően finoman lehet megkülönböztetni az eltérő értékajánlatokat.

\section{Személyre szabott árazás, aktuálisan optimális ár}

$\mathrm{Az}$ optimális árat minden egyes vevőre külön meghatározva személyre szabott optimális árról beszélhetünk, ami - ideális esetben - az ügyfél rezervációs ára. (Ha az optimális ár nagyobb a rezervációs árnál, akkor a vásárló nem fog vásárolni, ha pedig kisebb, akkor profitot veszít a kereskedő.)

A személyre szabott árazás mindeddig azért nem terjedt el a gyakorlatban, mert az ár meghatározása (személyes adatok elemzése, kedvezmény megállapítása, jogi korlátozások, pl. GDPR betartása) számottevő időbe és költségbe került volna. Amint ezek a költségek elhanyagolhatók lesznek, és gyakorlatilag valós időben rendelkezésre állnak, akkor használatuk is terjedni fog.

Elképzelhető, hogy egy olyan potenciális vásárló érdeklődik egy termékünk iránt, akinek a rezervációs ára alacsonyabb az aktuális optimális fogyasztói árnál: tetszik a vevő számára a termék, meg is venné, de drágának találja, mert például a konkurenciánál olcsóbban látta a terméket, vagy egy helyettesítő termék alacsonyabb áron elérhető. Ebben az esetben döntenünk kell, hogy a vásárlónak megadjuk-e azt a kedvezményt, amivel eléri a rezervációs árát, vagy pedig rábeszéléssel megpróbáljuk növelni a rezervációs árát. 
Ha a rezervációs ár mellett még marad elég profit, akkor valószínüleg érdemes megadni a kedvezményt, mert egyébként a potenciális vevőt (akár örökre) elveszítjük. Ennek a taktikának fontos előfeltétele, hogy a megállapított rezervációs ár pontos legyen, és az árkedvezmény tényleg vásárlásra ösztönözze a vásárlót.

A személyre szabott árazás ugyanakkor társadalmi és jogi kérdéseket is felvet, amelyekkel itt nem foglalkozunk, de több országban már elemzik a felhasználhatóság korlátait (Orlowski 2018, Zander-Hayat et al. 2016).

\section{VEVŐI OLDAL}

A MI eszközei nem csak a kereskedő számára lehetnek hasznosak, hanem a vásárló számára is, ezért többféle árazástámogató eszköz fog elterjedni a vevői oldalon is. A teljesség igénye nélkül bemutatunk néhány várható megoldást:

- A támogató rendszerek - megfelelő becslésekkel - meg fogják tudni határozni a vásárolt termék teljes bekerülési költségét (szállítással, kötelező tartozékokkal, stb.), ami fontosabb összemérési alap lesz, mint maga a fogyasztói ár.

- Elterjedhet a termékek életciklus (teljes élettartam) költségszámítása, amibe pl. a garancia is beletartozik. Így a vásárló nem csak a közvetlen fogyasztói árakat tudja majd összehasonlítani, hanem több évre vonatkozóan a várható teljes fenntartási költséget, pl. egy mosógép esetén az áram- és mosószerfogyasztás, valamint karbantartás és javítás költségeit.

- Meg fognak jelenni azok a tanácsadó rendszerek, amelyek megmondják, hogy mit, mikor, mennyiért érdemes vásárolni. Az ajánló rendszer szól a tulajdonosnak, hogy mikor ér el egy adott termékakció olyan ár-érték arányt, amikor már érdemes megfontolni a vásárlást. Várhatóan elterjednek azok az „okos” árfigyelö, akciófigyelö, árelemző termékek és szolgáltatások, amelyek MI algoritmusokon alapulnak és személyes preferenciákat (márka, minőség, árkategória) is figyelembe vesznek.

- A tanácsadó rendszerek hatására a vásárlói oldal is fellép árigénnyel. Noha elvileg erre most is lenne lehetőség, a kereskedőknek egyelőre túl drága egyéni igényekkel foglalkozni, de egyes aukciós portálokon már kísérleti jelleggel próbálkoznak ezzel a lehetőséggel. A vásárlói oldal megszólításával megvalósulhat az árigények mérése, ami pedig finomabbá teheti a rezervációs ár meghatározását.

\section{ÖSSZEFOGLALÁS}

A következő évtizedben a kereskedőknek egy új eszközcsalád fog majd rendelkezésre állni (kezdetben megkülönböztető jelleggel), hogy profitot növeljenek. Nem csak a gépi tanulás, hanem MI algoritmusokkal támogatott adatelemzések és kommunikációs megoldások is támogatni fogják az eladókat, majd - időben kissé később a vevőket is. Bemutattam, hogy a dinamikus és értékalapú árazások egyre jobban elterjednek a lakossági kereskedelemben. Az MI korban az olyan árazáshoz kapcsolódó közgazdasági elméleti fogalmak, mint rezervációs ár vagy árrugalmasság egyre pontosabban számíthatókká válnak, lehetővé téve az optimális ár meghatározását a kereskedők számára. A dolgozatban bemutattam az optimális ár kiszámításának egy olyan lehetséges folyamatát, ami arra épít, hogy MI eszközök felhasználásával jó közelítéssel becsülni lehet majd a termékek árrugalmasságát és a vevők rezervációs árát. Megállapítottam, hogy a jövőben az egydimenziós „ár” elavul, és jellemzőn három dimenziójú árakról fogunk beszélni, idő- és vevődimenziókat is figyelembe véve. Az MI számításokhoz és az adatvezérelt árazáshoz sok adatra lesz szükség, amihez kapcsolódóan csoportosítottam a felhasználható adatforrásokat. 


\section{HIVATKOZÁSOK}

Bara Z. (2017), „Dinamikus árazás az online kereskedelemben - Hogyan lehet hátrányos a fogyasztónak a dinamikus árazás?", Versenytükör 2017/2, pp. 5-18.

den Boer, A. V. (2015), „Dynamic pricing and learning: Historical origins, current research, and new directions" Surveys in Operations Research and Management Science, 20 1, 1-18

Danyi, P. (2019) „A mesterséges intelligencia az árazásban" Marketing és Menedzsment, 52 3-4, 5-18

Macdivitt, H., Wilkinson, M. (2012) Value-based Pricing, McGraw-Hill

Orlowski, A. (2018), „UK.gov asks: Are sadistic AI price-bots ganging up on you?", 2018.10.12. https://www.theregister.co.uk/2018/10/12/ uk_government_digital_competition_inquiry/, letöltve: 2018.11.05.
Rekettye G. (2012), „Az árak észlelése és értékelése", Vezetéstudomány, XLIII 5, 2-13

Rekettye G. (2018) „Gondolatok a digitalizáció fejlődéséről és az árakra gyakorolt hatásáról"' In: Dobrai K., László Gy., Sipos N. (szerk.) Ferenc Farkas Int'l Scientific Conference, Pécs, Magyarország , 2018.06.07 -2018.06.08. Pécsi Tudományegyetem Közgazdaságtudományi Kar Vezetés- és Szervezéstudományi Intézet, pp. 245-261.

Rekettye G. - Liu, J. (2018), Pricing: The New Frontier, Transnational Press London

Smith, T. J. (2012), Pricing Strategy: Setting Price Levels, Managing Price Discounts, \& Establishing Prie Structures, South-Western, Cengage Learning

Zander-Hayat, H., Domurath, I., Gross, C. (2016), Personalisierte Preise, Sachverständigenrat für Verbraucherfragen beim Bundesministerium der Justiz und für Verbraucherschutz, August

Danyi Pál PhD, egyetemi docens danyi@mvt.bme.hu

Budapesti Müszaki és Gazdaságtudományi Egyetem Menedzsment és Vállalkozásgazdaságtan Tanszék

\section{Expected impact of Artificial Intelligence on Pricing}

\section{THE AIMS OF THE PAPER}

Technology and tools of Artificial Intelligence (AI) will disseminate in more and more business areas in the near future, including marketing and pricing. Our aim is to present how data driven techniques will impact on pricing and change the pricing practices of enterprises.

\section{METHODOLOGY}

In this conceptual study I analyzed the expected impact of AI methods, based on the detailed research I carried out earlier. My study inspects the most important process steps of pricing.

\section{MOST IMPORTANT RESULTS}

I prove in my research that data driven technologies supported by AI tools will bring fundamental changes in pricing in the next decade. I developed a potential AI-based process of establishing optimal prices. I offer a proposal to expand the one dimensional price of a product into three dimensions including time and customer.

\section{RECOMMENDATIONS}

Value-based and dynamic pricing will spread widely due to AI. Reservation price, price elasticity, and optimal price are those theoretical concepts that will gain practical relevance with the usage of AI: all companies will be able to calculate those values by which profit can be increased significantly.

Keywords: artificial intelligence, intelligent pricing, dynamic pricing, machine learning, data driven, optimal price, personalized price 